\title{
THE INFLUENCE OF THE TYPE AND WIDTH OF THE CUT MARKER ON THE UTILIZATION OF TEXTILE MATERIALS
}

Silvana Zhezhova ${ }^{1 *}$, Goran Demboski², Vineta Srebrenkoska ${ }^{1}$, Sonja Jordeva ${ }^{1}$, Sashka Golomeova Longurova ${ }^{1}$

1 University "Goce Delchev", Faculty of Technology, Shtip, R.N. Macedonia

2University "Ss. Cyril and Methodius", Faculty of Technology and Metallurgy, Skopje, R.N. Macedonia

Textile material is the biggest cost driver of the apparel industry, reaching up to $75 \%$ of total production cost, so even minimal fabric savings directly affects the overall production costs. Based on the data given in the work order in terms of quantities, sizes and colors, the cut order plan makes efforts to minimize the total production costs by developing an optimal cut order plan in terms of available quantities of material, machinery and labor. Marker has a direct impact on fabric consumption. The choice of the cut marker type depends on the type of garment, textile material structure and work order size. Understanding how to reduce consumption of textile materials, or in other words said increasing the utilization of cut markers is of great importance for technical preparation in the apparel industry, due to their important role in controlling material costs. The aim of this paper is to investigate the effect that the type and width of markers has on the consumption and utilization of textile materials.
(PROFESSIONAL PAPER) UDC 687.016:677.074

Keywords: Material cost, cut order plan, cut marker, fabric consumption, marker utilization, apparel industry

\section{Introduction}

The focus of efficiency in the apparel industry is to reduce the cost of raw materials (material costs), which often reach up to $75 \%$ of total production costs. In recent years we have witnessed a steady increase in the prices of textile materials, so any higher percentage of utilization of materials achieved directly affects the overall production costs [1]. The cut order planning process, spreading and cutting process in the cutting department, determine the utilization of textile materials [2].

The apparel industry dedicates great attention to the planning of work orders, which play a significant role in the management of material costs. Based on the data given in the work order in terms of quantities, sizes and colors, the cut order plan makes efforts to minimize the total production costs by developing an optimal cut order plan in terms of available quantities of material, machinery and labor [3]. In fact, the planning of work orders for cutting is an activity that takes into account the production objectives and transforms the work orders into cut order plans in the most efficient way. The cut order plan contains detailed instructions regarding the required number of cutting markers, basic data for individual markers, the number of piles in the individual cutting lay and the required amount of textile material [4].

Marker has a direct impact on fabric consumption. The choice of cut marker type depends on the type of garment, the structure of textile material and the size of work order.
An emphasis is placed on the marker utilization because of their important role in controlling material costs $[5,6]$. Figure 1 provides a concise overview of the factors affecting marker utilization.

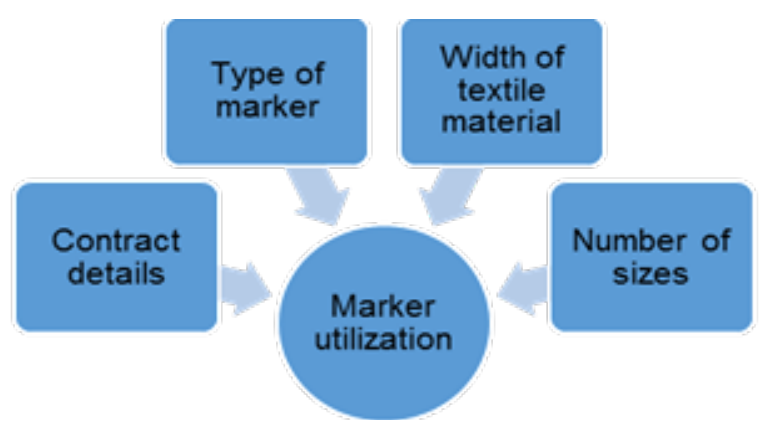

Figure 1. Factors affecting marker utilization

Markers can be categorized into three groups with respect to the required sizes in work order (customer demand table):

1. One-size markers (markers that have only one size, e.g. $38,40,42$ )

2. Two-size markers (markers that have at least two sizes that are absolutely different, e.g. 38-40, 38-44)

3. Multi size markers (markers that have more than two sizes that can be repeatedly used on the same marker, e.g. 38-38-48-48, 38-40-46-48)

In practice, planners try to combine smaller size units

\footnotetext{
*Author address: Silvana Zhezhova, University “Goce Delchev”, Faculty of Technology, „Krste Misirkov“ No.10-A P.O. Box 201, Stip 2000, R. N. Macedonia

E-mail: silvana.zezova@ugd.edu.mk

The manuscript received: October, 30, 2019.

Paper accepted: December, 02, 2019.
} 
with larger size units, because they try to assign as many parts as possible to each marker to maximize material utilization.

The width of the marker depends on the width of fabric roll which is typically assumed to be constant in many studies [7]. Different width of textile rolls for the same work order that varies a few centimeters, can be a problem for technical preparation in the apparel industry regarding the width of the markers that need to be constructed. The length of each marker is limited and generally depends on a planner or a cutting table length [8].

The question is, are there any significant differences in the consumption of textile material for different widths of cut markers? Is it possible to construct a cut marker according to the minimum width of the textile materials or to construct cut markers at intervals of more than one width?

\section{Experimental}

In order to examine the effect that type and width of markers have on the consumption and utilization of textile materials, two variants of work orders, which differ in their structure and type of clothing product, were analyzed. The structure of the analyzed work orders is shown in Tables 1 and 2 respectively.

The following variants of technical and technological factors were applied in the design of cut order plans, for the two analyzed variants of work orders:

- one size cut marker;

- two size cut marker;

- a larger multi size cut marker,

- two different widths of textile material, which differ from one another by $1-2 \mathrm{~cm}$,

- maximum length of mass for laying on cutting layers of $8,5 \mathrm{~m}$;

Table 1. Structure of work order A for men's pants

\begin{tabular}{ccccccccc}
\hline & \multicolumn{10}{c}{ Designation of work order : A } & Total: \\
\hline Size & 38 & 40 & 42 & 44 & 46 & 48 & $48 \mathrm{~B}$ & $\mathbf{2 7 4}$ \\
Quantity & $\mathbf{2 3}$ & $\mathbf{5 4}$ & $\mathbf{6 2}$ & $\mathbf{6 0}$ & $\mathbf{5 3}$ & $\mathbf{1 8}$ & $\mathbf{4}$ &
\end{tabular}

Table 2. Structure of work order B for children's pants

\begin{tabular}{cccccccccc}
\hline \multicolumn{10}{c}{ Designation of work order: B } \\
\hline Size & 4 & 6 & 8 & 10 & 11 & 12 & 14 & 16 & Total: \\
Quantity & $\mathbf{3 4}$ & $\mathbf{2 3}$ & $\mathbf{2 3}$ & $\mathbf{3 6}$ & $\mathbf{2 3}$ & $\mathbf{3 6}$ & $\mathbf{3 6}$ & $\mathbf{2 1}$ & $\mathbf{2 3 2}$ \\
\hline
\end{tabular}

Table 3. Structure of the cut order plan for work order A

\begin{tabular}{cccccc}
\hline \multicolumn{7}{c}{ CUT PLAN FOR WORK ORDER A } \\
\hline $\begin{array}{c}\text { One-size markers } \\
\text { Number of } \\
\text { sizes }\end{array}$ & $\begin{array}{c}\text { Number of } \\
\text { piles }\end{array}$ & $\begin{array}{c}\text { Two-size markers } \\
\text { Number of } \\
\text { sizes }\end{array}$ & $\begin{array}{c}\text { Number of } \\
\text { piles }\end{array}$ & $\begin{array}{c}\text { Multi size markers } \\
\text { Number of } \\
\text { sizes }\end{array}$ & $\begin{array}{c}\text { Number of } \\
\text { piles }\end{array}$ \\
\hline $38 \times 1$ & 23 & $38 \times 1 ; 48 \times 1$ & 18 & $38 \times 1 ; 40 \times 1 ; 46 \times 1 ; 48 \times 1$ & 18 \\
$40 \times 1$ & 54 & $38 \times 1 ; 48 \mathrm{~B} \times 1$ & 5 & $40 \times 2 ; 46 \times 2$ & 17 \\
$42 \times 1$ & 62 & $42 \times 1 ; 44 \times 1$ & 62 & $42 \times 2 ; 44 \times 2$ & 31 \\
$44 \times 1$ & 60 & $40 \times 1 ; 46 \times 1$ & 54 & $38 \times 2 ; 48 \mathrm{~B} \times 2$ & 3 \\
$46 \times 1$ & 53 & & & & \\
$48 \times 1$ & 18 & & & & \\
$48 \mathrm{Bx} 1$ & 4 & & & & \\
Total: & $\mathbf{2 7 4}$ & & & & \\
\hline
\end{tabular}

Table 4. Structure of the cut order plan for work order B

\begin{tabular}{cccccc}
\hline \multicolumn{7}{c}{ CUT PLAN FOR WORK ORDER B } \\
$\begin{array}{c}\text { Number of } \\
\text { sizes }\end{array}$ & $\begin{array}{c}\text { Number of } \\
\text { piles }\end{array}$ & $\begin{array}{c}\text { Twmo-size markers } \\
\text { Number of } \\
\text { siz }\end{array}$ & $\begin{array}{c}\text { Number of } \\
\text { piles }\end{array}$ & $\begin{array}{c}\text { Multi size markers } \\
\text { Number of } \\
\text { sizes }\end{array}$ & $\begin{array}{c}\text { Number of } \\
\text { piles }\end{array}$ \\
\hline $4 \times 1$ & 34 & $4 \times 1 ; 14 \times 1$ & 36 & $4 \times 1 ; 10 \times 1 ; 12 \times 1 ; 14 \times 1$ & 36 \\
$6 \times 1$ & 23 & $6 \times 1 ; 16 \times 1$ & 23 & $6 \times 1 ; 8 \times 1 ; 11 \times 1 ; 16 \times 1$ & 23 \\
$8 \times 1$ & 23 & $8 \times 1 ; 11 \times 1$ & 23 & & \\
$10 \times 1$ & 36 & $10 \times 1 ; 12 \times 1$ & 36 & & \\
$11 \times 1$ & 23 & & & & \\
$12 \times 1$ & 36 & & & & \\
$14 \times 1$ & 36 & & & & \\
$16 \times 1$ & 21 & & & & \\
Total: & $\mathbf{2 3 2}$ & & & & \\
\hline
\end{tabular}



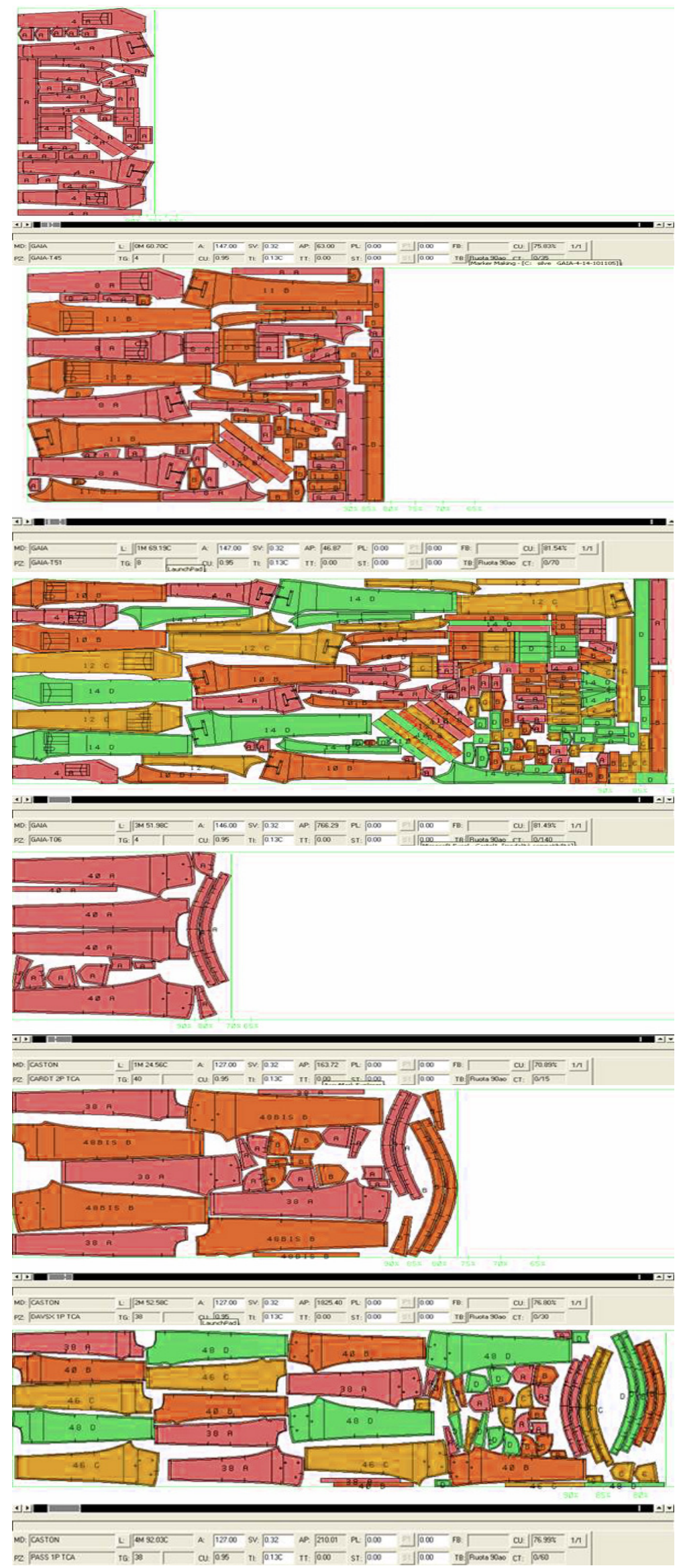

Figure 2. Variants of manufactured marker for work order $A$ and $B$ 
Tables 3 and 4 show the cut order plans for work orders $A$ and $B$, formed in different variants of technical and technological factors.

Based on the data from the cut order plans (Table 3 and 4 ), the required cut markers were created using a AccuMark Marker Making by Gerber. Figure 2 presents several variants of manufactured markers for work orders $A$ and $B$ respectively.

\section{Results and discussion}

Tables 5 and 6 show the experimental results obtained for the consumption and utilization of a textile material when processing work order $\mathrm{A}$ according to the cut order plan given in Table 3, for two different widths of markers $(1,27$ and 1,29 m). The basic data (width, length and corresponding utilization percentage \%) for each of the cut markers were obtained from the manufactured markers.

Table 5. Utilisation and consumption of fabric for different types of cut markers for fabric width 1,27 m (Work order A)

\begin{tabular}{|c|c|c|c|c|c|c|}
\hline \multirow{3}{*}{$\begin{array}{c}\text { Work order } \\
\text { A }\end{array}$} & \multicolumn{6}{|c|}{ TYPE OF MARKER } \\
\hline & \multicolumn{2}{|c|}{ One-size markers - 1} & \multicolumn{2}{|c|}{ Two-size markers - 2} & \multicolumn{2}{|c|}{ Multi size markers 3} \\
\hline & I (\%) & $\mathrm{L}(\mathrm{m})$ & I (\%) & $L(m)$ & I (\%) & $L(m)$ \\
\hline & 71,80 & 27,6 & 75,12 & 45,9 & 76,99 & 89,10 \\
\hline & 70,89 & 69,12 & 76,80 & 12,8 & 81,94 & 79,05 \\
\hline & 72,80 & 80,60 & 77,42 & 153,14 & 79,15 & 149,1 \\
\hline & 73,07 & 81,00 & 75,76 & 136,62 & 77,97 & 14,67 \\
\hline & 74,47 & 73,67 & & & & \\
\hline & 73,36 & 26,46 & & & & \\
\hline & 65,80 & 6,80 & & & & \\
\hline Total: & I $\mathrm{pr}=71,74$ & 365,25 & $\mathrm{I} p r=76,27$ & 348,46 & $\mathrm{l} p \mathrm{pr}=79,01$ & 331,93 \\
\hline
\end{tabular}

Table 6. Utilisation and consumption of fabric for different types of cut markers for fabric width 1,29 $\mathrm{m}$

\begin{tabular}{|c|c|c|c|c|c|c|}
\hline \multicolumn{7}{|c|}{ (Work order A) } \\
\hline \multirow{2}{*}{$\begin{array}{c}\text { Work order } \\
\text { A }\end{array}$} & \multicolumn{6}{|c|}{$\begin{array}{l}\text { TYPE OF MARKER } \\
\end{array}$} \\
\hline & I (\%) & $L(m)$ & I (\%) & $L(m)$ & I (\%) & $L(m)$ \\
\hline & 70,70 & 27,6 & 73,94 & 45,9 & 76,67 & 88,02 \\
\hline & 69,89 & 68,58 & 75,89 & 12,75 & 81,49 & 78,20 \\
\hline & 71,67 & 80,60 & 76,69 & 152,52 & 78,07 & 148,80 \\
\hline & 73,71 & 79,2 & 74,73 & 136,08 & 78,98 & 14,28 \\
\hline & 73,81 & 73,14 & & & & 329,30 \\
\hline & 74,52 & 25,56 & & & & \\
\hline & 68,38 & 6,44 & & & & \\
\hline Total: & $\mathrm{I} p r=71,81$ & 361,12 & I pr $=75,31$ & 347,25 & $\mathrm{I} p \mathrm{pr}=\mathbf{7 8 , 8 0}$ & 329,30 \\
\hline
\end{tabular}

Table 7. Utilisation and consumption of fabric for different types of cut markers for fabric width 1,46 m

\begin{tabular}{|c|c|c|c|c|c|c|}
\hline \multicolumn{7}{|c|}{ (Work order B) } \\
\hline \multirow{2}{*}{$\begin{array}{l}\text { Work order } \\
\text { B }\end{array}$} & \multicolumn{2}{|c|}{ One-size markers 1} & \multicolumn{2}{|c|}{$\begin{array}{l}\text { TYPE OF MARKER } \\
\text { Two-size markers - } 2\end{array}$} & \multicolumn{2}{|c|}{ Multi size markers - 3} \\
\hline & I (\%) & $L(m)$ & I (\%) & $L(m)$ & I (\%) & $L(m)$ \\
\hline & 76,35 & 21,76 & 82,07 & 60,12 & 81,49 & 81,65 \\
\hline & 76,30 & 17,02 & 82,70 & 42,09 & & 125,28 \\
\hline & 78,54 & 19,09 & 81,23 & 40,02 & & 206,93 \\
\hline & 77,39 & 34,56 & 81,57 & 68,4 & & \\
\hline & 79,30 & 22,77 & & & & \\
\hline & 77,49 & 38,52 & & & & \\
\hline & 80,25 & 40,68 & & & & \\
\hline & 82,04 & 24,78 & & & & \\
\hline Total: & I $\mathrm{pr}=78,45$ & 219,18 & $I \mathrm{pr}=81,89$ & 210,63 & I pr =82,46 & 206,93 \\
\hline
\end{tabular}

Table 8. Utilisation and consumption of fabric for different types of cut markers for fabric width 1,47 $\mathrm{m}$

\begin{tabular}{|c|c|c|c|c|c|c|}
\hline \multirow{4}{*}{$\begin{array}{c}\text { Work order } \\
\text { B }\end{array}$} & \multicolumn{6}{|c|}{ (Work order B) } \\
\hline & \multirow{2}{*}{\multicolumn{2}{|c|}{ One-size markers - 1}} & \multirow{2}{*}{\multicolumn{2}{|c|}{$\begin{array}{l}\text { TYPE OF MARKER } \\
\text { Two-size markers - } 2\end{array}$}} & \multirow{2}{*}{\multicolumn{2}{|c|}{ Multi size markers - 3}} \\
\hline & & & & & & \\
\hline & I (\%) & L (m) & I (\%) & $\mathrm{L}(\mathrm{m})$ & I (\%) & $L(m)$ \\
\hline & 75,83 & 21,76 & 81,82 & 9,76 & 83,10 & 79,58 \\
\hline & 77,90 & 16,56 & 82,64 & 41,86 & 84,29 & 123,12 \\
\hline & 79,07 & 18,86 & 81,54 & 39,56 & & \\
\hline & 77,44 & 34,20 & 81,57 & 67,68 & & \\
\hline & 79,15 & 22,54 & & & & \\
\hline & 76,96 & 38,52 & & & & \\
\hline & 80,06 & 40,32 & & & & \\
\hline & 82,47 & 24,57 & & & & \\
\hline Total: & $\mathrm{I} p \mathrm{pr}=\mathbf{7 8 , 6}$ & 217,33 & $\mathrm{pr}=\mathbf{p 1 , 8 9}$ & 208,86 & I pr $=83,69$ & 202,7 \\
\hline
\end{tabular}


Tables 7 and 8 show the results obtained from processing work order $\mathrm{B}$ according to the cut order plan given in Table 4 for marker width (1,46 and 1,47 m).

The results from Tables 5 and 6 are shown in the diagram (Figures 3 and 4). The diagram (Figure 3 ) shows the influence of the type and width of cut markers $(1,27$ and $1,29 \mathrm{~m}$ ) on the average utilization of material Ipr (\%) for work order $\mathrm{A}$. The diagram (Figure 4) shows the dependence of the consumption of textile material on the type of cut marker for two different marker widths $(1,27$ and $1,29 \mathrm{~m})$.

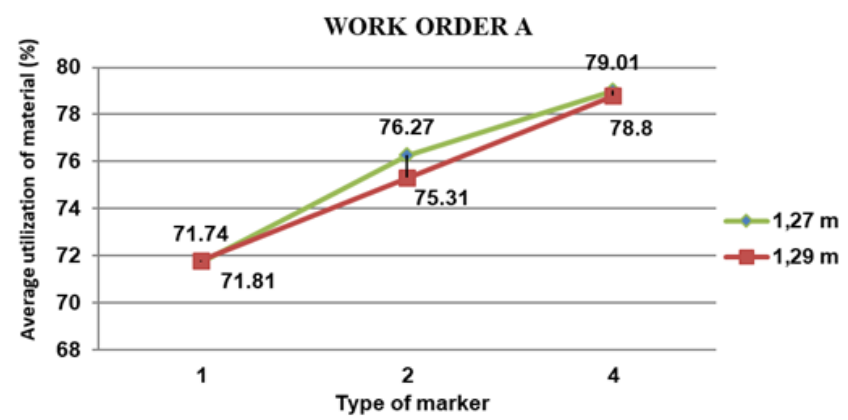

Figure 3. The effect of cut marker type and width $(1,27$ and $1,29 \mathrm{~m}$ ) on the average utilization of textile material for work order A

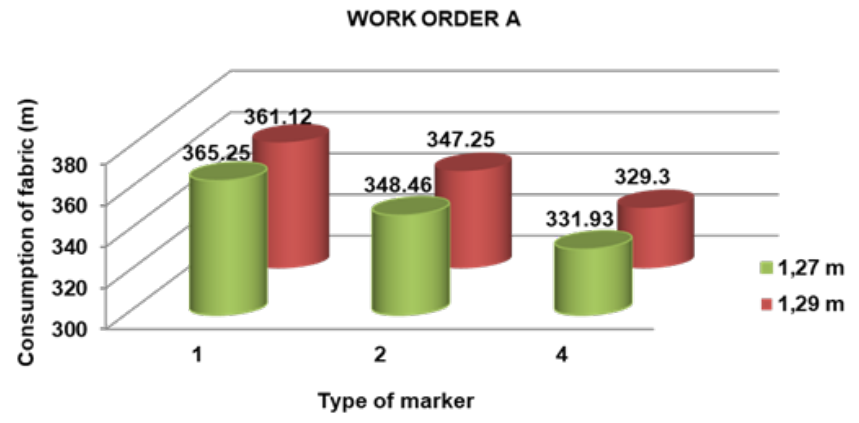

Figure 4. The effect of cut marker type and width $(1,27$ and $1,29 \mathrm{~m}$ ) on the consumption of textile material for work order $A$

In Figures 3 and 4, the diagrams show that the use of multi-size cut markers gives significant savings in textile material, by increasing the utilization rate and reducing the consumption of the textile material. The experimental results shown in the diagram in Figure 3 show that the utilization rate of the cut markers increases from $(71,74$ $/ 71,81) \%$ for one size cut markers to $(79,01 / 78,8) \%$ for the multi size markers, or increases on average for $7 \%$. The diagram in Figure 4 shows that when multi size cut markers are used (1,27 and 1,29 m), (33,32 / 31,82 meters) or $(9,1 / 8,8) \%$, less textile material is required in relation to one size cut markers.

The experimentally obtained values for the effect of marker width on utilization show that there are slight changes (Figures 3 ). The fabric utilization rate from one width $(1,29 \mathrm{~m})$ to another width $(1,27 \mathrm{~m})$ is slightly increased $(71,74 / 71,81) \%$ or decreased $(76,27$ / 75,31; $79,01 / 78,8) \%$. Also, there are no significant differences in the consumption of the fabric, when the difference in the marker width is $2 \mathrm{~cm}$ (Figure 4). The realized saving on the fabric ranges from 1,21 to 4,13 meters.

The results from Tables 7 and 8 are shown in the diagrams in Figures 5 and 6 . The diagram in Figure 5 shows the effect of the type and width of the marker on the average material utilization, Ipr (\%), while the diagram in Figure 6 shows the effect of the marker width on material consumption for two different marker widths (1,46 and $1,47 \mathrm{~m}$ ) for work order B.

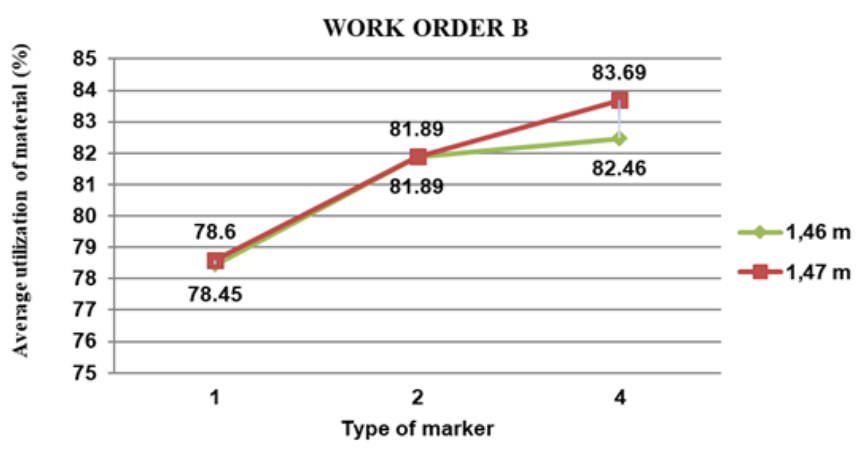

Figure 5. The effect of cut marker type and width (1,46 and $1,47 \mathrm{~m}$ ) on the average utilization of textile material for work order B

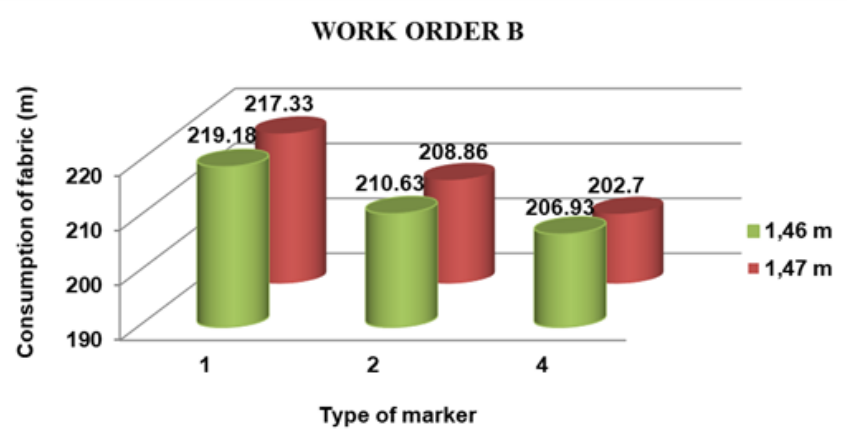

Figure 6. The effect of cut marker type and width (1,46 and $1,47 \mathrm{~m}$ ) on the consumption of textile material for work order $B$

The diagrams (Figures 5 and 6 ) follow the tendencies previously observed (Figures 3 and 4), which means that, depending on the choice of marker, there are significant differences in the utilization and consumption of textile materials. The experimental results from the diagram in Figure 5 show that the utilization rate of multi size markers increased by an average of about $4,5 \%$ relative to one size markers. The diagram shows that using multi size markers (1,46 and 1,47 m), (12,25/14,63 meters) or $(5,6 / 6,7) \%$ less textile material is required in relation to single-size markers (Figure 6). The obtained results of the effect of marker width on the utilization show that there are slight changes (Figure 5). Fabric utilization rate from one width $(1,47 \mathrm{~m})$ to another width $(1,46 \mathrm{~m})$ is slightly increased $(0,15-1,23) \%$ or not changed at all. The experimentally obtained values for the effect of marker width on textile material consumption, show that by increasing the marker width by $1 \mathrm{~cm}$, textile material savings of 1,77 - 4,23 meters is achieved (Figure 6). 


\section{Conclusion}

The obtained result leads to the conclusion that the type of marker and the type of garment have a large influence on the utilization and consumption of textile materials. Significant textile material savings can be achieved by using multiple size markers. The number of required layers in cut order plans is also significantly reduced, which contributes to lower labor costs. The analyzes performed when testing the effect of marker width on the utilization and consumption of textile materials show that by increasing marker width by $1-2 \mathrm{~cm}$, the saving of 2 - 4 meters is achieved and the saving in textile material consumption is negligible. Based on the obtained results it can be concluded that when marker width is increased from 1 to $2 \mathrm{~cm}$, textile material utilization rate increases, decreases or does not change at all.

\section{References}

[1] C. Jacobs - Blecha, J. C., Ammons, A. Schutte, T. Smith, Cut order planning for apparel manufacturing, IIE Transactions, Springer 30 (1), (1998) 79 - 90.

[2] A. Beazley, T. Bond, Computer aided pattern design and product development, Blackwell Science Ltd., 2003, p. 1-20.

[3] T. F. Wallace, R. A. Stahl, Master scheduling in the 21st century: for simplicity, speed, and success, T. F. Wallace \& Company, USA, 2013 p. 85 - 98.

[4] G. Cooklin, S. G. Hayes, J. McLoughlin, Introduction To Clothing Manufacture, Blackwell Publishing Ltd, (2006) $85-99$.

[5] E. Dumishllari, G. Guxho, Impact of Marker on Cut Plan in Garment Production, International Journal of Innovative Research in Science, Engineering and Technology, 4 (8), (August 2015).

[6] P. Puranik, S. Jain, Garment Marker Planning - A Review, International Journal of Advanced Research in Education \& Technology (IJARET), 4 (2), (April - June 2017).

[7] A. Mausmi, Fabric Utilization, Cut Order Planning, Stitch World, June 2013.

[8] D. J. Tyler, Carr and Latham's Technology of Clothing Manufacture, 4nd edition, Blackwell Publishing Ltd, (2008) $6-51$.

\section{Izvod \\ UTICAJ VRSTE I ŠIRINE KROJNE SLIKE NA ISKORIŠĆENJE TEKSTILNIH MATERIJALA}

Silvana Žežova ${ }^{1}$, Goran Demboski², Vineta Srebrenkoska ${ }^{1}$, Sonja Jordeva1 Saška Golomeova Longurova ${ }^{1}$

1Univerzitet “Goce Delčev”, Tehnološko-tehnički fakultet, Štip, R.S. Makedonija

2Univerzitet “Sv. Kiril i Metodij”, Tehnološko-metalurški fakultet, Skoplje, R.S. Makedonija

U proizvodnji odeće troškovi za tekstilni materijal iznose oko $75 \%$ od ukupnih troškova proizvoda, što znači da čak i mala ušteda materijala smanjuje ukupne troškove. Na osnovu podataka datih u radnom nalogu u pogledu količine, veličine i boja, plan krojenja ulaže napore da minimizira ukupne troškove proizvodnje razvijajući optimalan plan krojenja u pogledu raspoloživih količina materijala, mašina i radne snage. Krojne slike imaju direktan uticaj na potrošnju tkanina. Izbor vrste krojne slike zavisi od vrste odeće, strukture tekstilnog materijala i veličine radnog naloga. Poznavanje načina smanjenja potrošnje tekstilnih materijala, odnosno veći stepen $\mathrm{i}$ iskorišćavanje krojne slike je od velikog značaja u industriji odeće, zbog važne uloge u kontroli troškova materijala. Cilj ovog rada je istražiti uticaj koji vrsta i širina krojne slike imaju na potrošnju i iskorišćenje tekstilnih materijala.
(STRUČNI RAD)

UDC 687.016:677.074

Ključne reči: Materijalni troškovi, plan krojenja, krojna slika, potrošnja tkanina, iskorišćenje krojne slike, industrija odeće. 